\title{
Dr. Sandra L. Wootton-Gorges (Oct. 20, 1958 - Jan. 23, 2017)
}

\author{
Rebecca Stein-Wexler ${ }^{1}$
}

Received: 31 January 2017 / Accepted: 2 February 2017 /Published online: 14 February 2017

(C) Springer-Verlag Berlin Heidelberg 2017

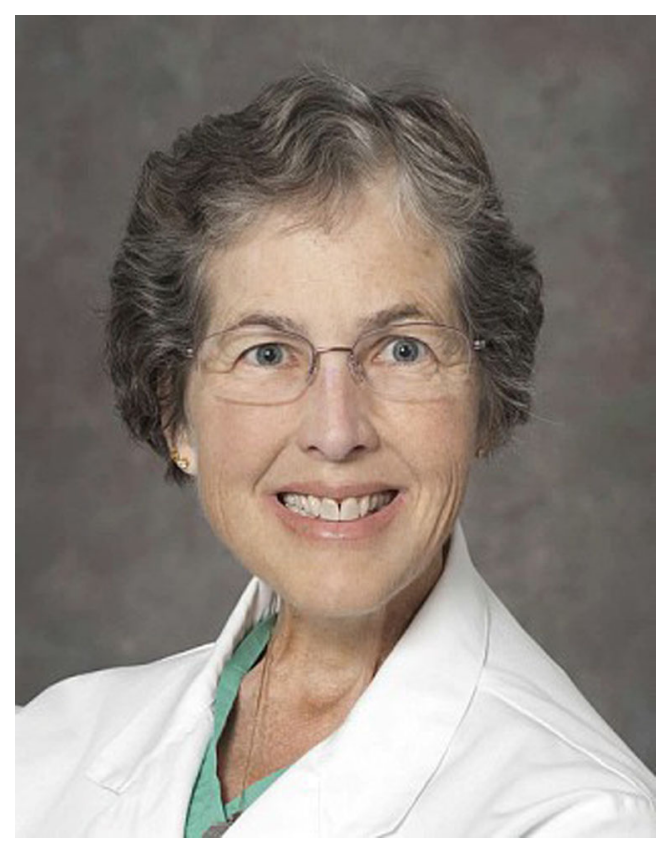

Dr. Sandra L. Wootton-Gorges was compassionate, caring, and humble, a mentor and role model for many. She passed away at the University of California Davis Medical Center at

Rebecca Stein-Wexler

rsteinwexler@ucdavis.edu

1 Division of Pediatric Radiology,

University of California Davis Medical Center,

and UC Davis Children's Hospital,

4860 Y St., Suite 3100, Sacramento,

CA 95817, USA age 58 after a brief illness that followed a litany of challenging medical problems. She was an incredible fighter who emerged from each illness invigorated, ready to enjoy her family and resume the challenges of academic pediatric radiology. Health concerns led Sandi to retire from UC Davis about 2 months ago. She wasn't quite ready to stop saving lives and making the world a better place for children and patients at large. But she felt it was time to focus more on family and friendships.

Sandi was born in El Paso, TX, and grew up in Fremont, CA. She was very close to her younger sister Lynda - so close that as teenagers they switched the " $i$ " in Linda and " $y$ " in Sandy, hence the distinct spelling of both their names. After graduating from Irvington High School in Fremont, Sandi stayed in the area for college, attending San Jose State University and graduating with a B.S. in chemistry in 1980 . Sandi would have become a marine biologist, but motion sickness drove her to medicine. She moved across the bay for medical school at the University of California San Francisco, graduating in 1985. Her internship in medicine was at Mt. Zion Hospital, also in San Francisco.

Sandi encouraged people to explore, saying, "You don't even know what's out there." When she explored radiology in medical school, she immediately knew it was her calling. She moved to San Diego to complete her residency in 1990. Her love of children and desire to help give them health and joy led her to specialize in pediatric radiology. She completed a 2-year fellowship in pediatric radiology at Boston Children's Hospital. As chief fellow, she was a fantastic, tireless, gifted teacher - as well as something of a dorm mother.

Sandi began her career at the University of Colorado Health Sciences Center in Denver in 1993. After 7 years, she returned to her family and her beloved California. She started as an assistant professor at the University of California Davis in 1999 and steadily moved her way up the ladder, becoming full professor in 2009. She was also the 
medical director of imaging at Shriner's Hospitals for Children-Northern California. In 2007 she became associate chair of quality. Throughout her years at UC Davis she was the director of pediatric imaging.

Sandi married Bill in May 1995. They had their daughter, Annie, in June 1996. Annie was Sandi's pride and joy, and Sandi attended every sports event, dance recital, and school function. She would talk about Annie to anyone who would listen. Sandi loved to organize activities for the extended family. She and Bill hosted a dinner almost every weekend that grew to include up to 15 people as her young nieces, cousins, and in-laws of in-laws had families of their own. And she adored animals. Her annual vacations in Hawaii were all about whales and snorkeling. Entering Sandi's house was like stepping into a miniature zoo. Watch out for the tortoise hibernating in the guest bathroom! Sandi surreptitiously fed her dogs whipped cream when she thought the family wasn't looking. She was an avid traveler and had booked a trip to Machu Picchu and the Galapagos Islands for September.

Sandi wrote more than 60 peer-reviewed papers (and was both patient and author of one). Her major interests were in radiation dose reduction, imaging in pediatric trauma, cerebral edema in patients with diabetic ketoacidosis (DKA), optimal imaging for pediatric malignancy, and developing American College of Radiology (ACR) appropriateness criteria. She authored many chapters and edited Pediatric Orthopedic Imaging, along with Mike Ozonoff and me.

Residents admired "Dr. Gorges" for her strength and her resolve. As soon as she identified a problem, she came up with a solution and followed that immediately with action. So change happened fast when she chaired the Patient Quality Improvement Committee. The entire department benefitted from her insight, common sense, and high standards. She'd say "What you do every day, from waking up to sleeping, is your legacy - so you better do it well." Sandi mentored residents and faculty alike, and was planning to continue to mentor several new faculty members in her retirement.

Sandi loved to teach - at the reading station and also in more formal settings. She taught national board reviews and continuing medical education. She inspired undergraduates, medical students, and residents to follow in her footsteps. Sandi received the departmental Award for Excellence in Teaching in 2001 and 2009 and the departmental Award for Excellence in Professionalism in 2004. The hospital awarded her the Physician Healthcare Recognition Award in 2015.

Sandi served as president of the Pacific Coast Pediatric Radiology Association from 2000 to 2001 and had been secretary/treasurer ever since. Pediatric Radiology gave her the Award for Excellence in Manuscript Review twice, in 2005 and 2009. More recently, she served on its editorial board as well as the CT/MRI and the Child Abuse committees at the Society for Pediatric Radiology. Until recently she served on several committees in the Children's Oncology Group as well as the ACR Pediatric Appropriateness Criteria Committee.

Sandi had a calm, thoughtful, creative, heartfelt approach to dilemmas, challenges, problems large and small. She was so wise. So caring, generous and compassionate. She will live on in our hearts and in the impact she has had on the care of children. As I write this, I can hear her saying: "Love your family, hug your friends, and take care of all the wonderful children in this world." She would want us to grieve with a smile, remembering the wonderful times we spent with her and knowing that she spent her whole life caring for our children. Sandi is survived by her loving husband and daughter, as well as multitudes of other family and friends who loved and cherished her. 